\title{
PELATIHAN PENGGUNAAN ALAT PENGHALUS KOTORAN TERNAK DI KELOMPOK TERNAK SIDOMAJU BANTUL YOGYAKARTA
}

\section{Empowering the Local Farmer at Sido Maju Bantul Livestock Group Yogyakarta to Use Fecal Grinder Equipment}

\author{
Soedarmanto Indarjulianto ${ }^{1)^{*}}$, Irkham Widiyono ${ }^{1)}$, Sarmin $^{2)}$, Claude Mona Airin ${ }^{2)}$ \\ ${ }^{1)}$ Departemen Ilmu Penyakit Dalam, Fakultas Kedokteran Hewan, Universitas Gadjah Mada. \\ ${ }^{2}$ Departemen Fisiologi, Fakultas Kedokteran Hewan, Universitas Gadjah Mada. \\ J1. Fauna No.2, Karangmalang, Depok, Sleman. 55281 Yogyakarta, Indonesia \\ Tel : +62-274-560862, Fax +62-274-560861
}

Article history

Received: Nov 30, 2020;

Accepted: Feb 3, 2021

* Corresponding author:

E-mail:

indarjulianto@ugm.ac.id

DOI: https://doi.org/

10.46549/igkojei.v2i1.168

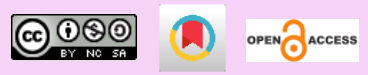

\begin{abstract}
The utilization of manure as organic fertilizer is on the rise, but the coarse form may negatively impact the aesthetics. This community service aims to train the farmers to operate the livestock manure grinder machine. The community service was performed in the Sidomaju livestock group, Panggungharjo village, Sewon, Bantul, Yogyakarta, with 37 farmers. The method for this community service is providing online presentations followed by online and offline workshops. The participation and satisfaction of the participants were measured by direct interaction and analyzed descriptively. The results of this community service showed that all farmers were more enthusiastic to participate in offline activities rather than online ones. All of the participants of the training can operate the livestock manure grinder machine. Based on the results of this activity, it is concluded that the training on the use of grinders for livestock manure machine has been adopted by farmers.
\end{abstract}

Keywords: manure; manure grinder; livestock; organic manure

\section{ABSTRAK}

Pemanfaatan kotoran ternak sebagai pupuk organik semakin meningkat, tetapi bentuk yang kasar dapat mengurangi estetika. Pengabdian kepada masyarakat ini bertujuan melaksanakan pelatihan penggunaan alat pelembut kotoran ternak. Pengabdian dilakukan di kelompok ternak Sidomaju, desa Panggungharjo, Sewon, Bantul, Yogyakarta yang beranggotakan 37 peternak. Metode kegiatan yang dilakukan adalah dengan presentasi dan pelatihan secara daring dan luring. Keterlibatan dan kepuasan peserta diukur melalui interaksi langsung dan hasilnya dianalisis secara deskriptif. Hasil pengabdian menunjukkan bahwa semua peternak lebih antusias mengikuti kegiatan secara luring. Semua peserta yang hadir dalam pelatihan telah dapat mengoperasionalkan mesin penghalus kotoran ternak. Berdasar hasil kegiatan ini, disimpulkan bahwa pelatihan penggunaan mesin penghalus kotoran ternak telah dapat diadopsi oleh peternak.

Kata kunci: kotoran ternak; pelembut kotoran; pupuk organik; ternak

\section{PENDAHULUAN}

Ruminansia, terutama sapi, kambing dan domba merupakan salah satu komediti ternak yang banyak dipelihara oleh peternak kecil di pedesaan di berbagai daerah di Indonesia. Beberapa jenis sapi yang banyak diternakkan adalah sapi potong, termasuk peranakan ongole, sapi silangan simental- 
PO (Simpo), sapi silangan limosin-PO (limpo), sapi bali (Matondang dan Rudiana, 2014; Putri dkk., 2014; Handayanta dkk., 2016; Sambodo dkk., 2019, 2020). Pemeliharaan ruminansia oleh petani peternak ini telah mendukung pemenuhan kebutuhan daging secara nasional baik untuk konsumsi sehari-hari maupun untuk keperluan hewan qurban (Dirjen-PKH, 2019; Sambodo dkk., 2020). Pemeliharaan sapi seringkali mendapat keluhan dari masyarakat sekitar usaha peternakan karena limbah kotorannya dianggap mencemari lingkungan. Namun sebaliknya, kotoran sapi mengandung bahan yang dapat dimanfaatkan sebagai material yang bermanfaat.

Pemanfaatan limbah kotoran ternak pada awalnya lebih banyak digunakan sebagai pupuk oraganik tanpa diolah. Seiring dengan kemajuan teknologi, limbah kotoran ternak telah dimanfaatkan sebagai bahan energi sebagai Biogas. Diversifikasi pengolahan limbah kotoran ternak sebagai pupuk telah dikembangkan antara lain pupuk organik hasil fermentasi, bokasi dan slury (Ningsih dkk., 2014; Irfan dkk., 2017). Pembuatan pupuk kompos berasal dari kotoran sapi telah banyak dikembangkan di berbagai wilayah dengan menggunakan berbagai bahan dan metode, termasuk menggunakan bahan Effective Microorganisme (EM) atau mikroorganisme lokal (MOL) sebagai mikroorganisme pengaktif (aktivator) agar proses fermentasi berlangsung lebih cepat (Hardianto, 2008; Juanda dkk., 2011; Nugraha dan Amini, 2013; Raden dkk., 2014). Pemanfaatan kotoran sapi sebagai pupuk organik juga telah banyak dimanfaatkan sebagai pupuk untuk tanaman kentang, bawang merah dan tanaman lainnya (Arifah, 2013; Raden dkk., 2014). Sayangnya bentuk pupuk asal kotoran ternak ini seringkali masih kasar, kurang homogen dan bahkan kadang masih ada tercampur kotoran yang masih berbentuk, terutama kotoran kambing/domba.

Bentuk pupuk yang masih kasar dapat diakibatkan karena limbah kotoran ternak hanya dikeringkan dan diaduk seperlunya secara manual. Kondisi pupuk tersebut juga masih ditemukan di Kelompok Ternak Sidomaju adalah kumpulan peternak yang memelihara ternak, khususnya sapi di desa Panggungharjo, Sewon, Bantul, Daerah Istimewa Yogyakarta. Seperti usaha ternak kecil lainnya, ternak peliharaan lebih sebagai tabungan dan dijual ketika membutuhkan uang (Handayanta dkk., 2016). Pemeliharaan yang dilakukan belum memperhatikan potensi limbah kotorannya secara optimal (Nugraha dan Amini, 2013). Limbah kotoran peternakan yang ada sementara ini diletakkan di sekitar kandang untuk dikeringkan dan setelah kering dimanfaatkan sebagai pupuk. Kotoran yang yang digunakan sebagai pupuk, biasanya tanpa melalui proses pengolahan atau dihaluskan terlebih dahulu. Aplikasi teknologi yang dapat dipakai untuk lebih menghaluskan bentuk pupuk asal kotoran hewan tersebut saat ini sangat diperlukan. Di sisi lain pemanfaatan teknologi penghalusan bahan telah diaplikasikan pada beberapa bahan antara lain pengolahan limbah perasan jahe menjadi tepung jahe dan biofarmaka lainnya (Paramawati dkk., 2008; Ngatirah dan Dewi, 2020). Kegiatan pengabdian kepada masyarakat ini merupakan rangkaian kegiatan sosialisasi sekaligus pelatihan penggunaan alat penghalus kotoran ternak untuk membantu peternak menggunakan alat penghalus kotoran. 


\section{METODE}

Kegiatan pengabdian kepada masyarakat (PKM) ini dilaksanakan pada bulan Agustus-Nopember 2020 di kelompok Ternak Sidomaju, dusun Kweni, desa Panggungharjo, kecamatan Sewon, Kabupaten Bantul, Daerah Istimewa Yogyakarta. Peserta pengabdian ini adalah anggota kelompok Ternak Sidomaju. Bahan yang digunakan adalah kotoran ternak yang sudah dikeringkan. Alat yang digunakan terutama adalah mesin penghalus kotoran (Gama Mixer).

Kegiatan pengabdian awalnya dilaksanakan secara daring dan dilanjutkan dengan sosialisasi dan pelatihan secara daring dan sekaligus luring di kandang kelompok ternak Sidomaju, Panggungharjo, Bantul. Keterlibatan dan keaktifan peserta diukur melalui pengamatan langsung pada saat pelaksanaan kegiatan. Data yang diperoleh selanjutnya dianalisis dan disampaikan secara deskriptif.

\section{HASIL DAN PEMBAHASAN}

PKM ini didahului dengan koordinasi dan sosialisasi berkaitan dengan program secara daring. Karena kurang efektifnya pelaksanaan kegiatan yang dilaksanakan secara daring, maka kegiatan sosialisasi dan pelatihan diadakan dengan modifikasi daring dan sekaligus dilanjutkan secara luring. Pada saat pelaksanaan kegiatan secara daring dan sekaligus luring petani peternak lebih antusias datang untuk mengikuti kegitan tersebut (Gambar 1). Peternak masih antusias mengikuti kegiatan sosialisasi secara luring daripada daring. Berbagai kegiatan komunikasi baik secara individu maupun kelompok dalam situasi wabah COVID-19 telah dilakukan secara daring oleh berbagai fihak. Sebagian besar peserta PKM ini sepertinya belum akrab dengan Webinar menggunakan berbagai aplikasi. Hal ini kemungkinan karena peternak masih terbiasa dengan komunikasi luring dan kurang nyaman menggunakan komunikasi daring. Penggunaan sistim daring ini sebetulnya sudah banyak dilakukan dengan menggunakan berbagai macam bentuk aplikasi, terutama di dunia pendidikan (Pradja dan Baist, 2019; Taufiqurrahman, 2020). Selain itu, kemungkinan juga disebabkan tidak semua peternak mempunyai fasilitas yang memadai dan ketersediaan koneksi internet. Kondisi yang sama juga dialami di dunia pendidikan sekolah dasar (SD) yang menggunakan sistim pembelajaran daring, seperti yang dilaporkan oleh Rahmawati (2009) dan Rigianti (2020) bahwa kendala yang dialami selama pembelajaran daring antara lain aplikasi pembelajaran, jaringan internet dan gawai. Oleh karena itu, kedepan sangat diperlukan sosialisasi sistim pembelajaran/komunikasi daring ini kepada masyarakat luas, termasuk petani peternak. 

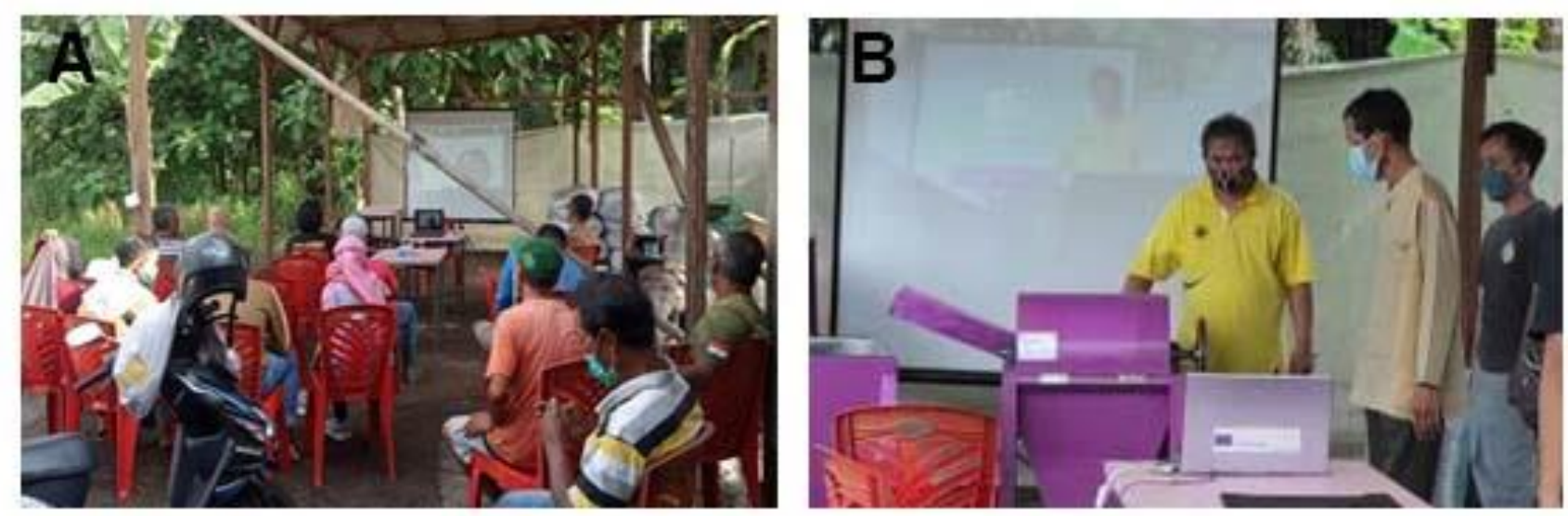

Gambar 1. Peternak sedang mengikuti sosialisasi secara daring (A) diteruskan dengan pelatihan secara luring (B)

Semua peternak yang hadir dalam kegiatan sosialisasi dan pelatihan secara luring ini antusias mengikuti sampai akhir acara. Mereka telah menyaksikan demonstrasi penggunaan alat (mesin) pencampur dan penghalus kortoran ternak dan dilanjutkan pelatihan mengoperasikannya oleh peternak dengan didampingi oleh teknisi. Peternak yang mencoba mesin tersebut sudah dapat mengoperasikannya, dengan hasil produksi yang lebih halus dibanding dengan produksi pupuk mereka sebelumnya (Gambar 2). Sosialisasi dan pelatihan secara luring lebih disukai oleh peternak, karena peternak tidak hanya dapat melihat dan mendengarkan saja, tetapi juga dapat langsung berinteraksi dengan narasumber dan mencoba mesin secara nyata. Kondisi ini sesuai dengan penelitian pelaksanaan pembelajaran di sekolah oleh Ekantini (2020) yang mendapatkan hasil pembelajaran IPA secara luring lebih efektif dibandingkan dengan pembelajaran IPA secara daring.
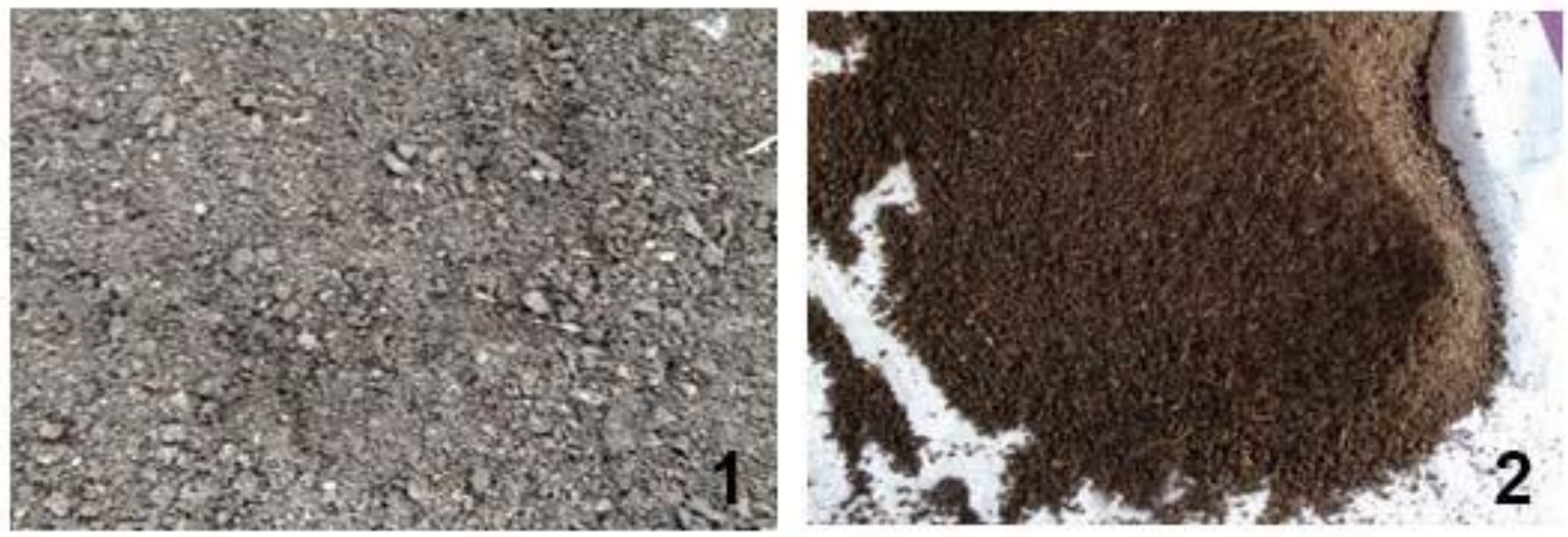

Gambar 2. Kotoran ternak sebelum dihaluskan (1) dan sesudah dihaluskan (2)

Peternak yang mengikuti sosialisasi berpendapat bahwa lebih halusnya pupuk asal kotoran ternak ini memberikan nilai tambah, karena partikelnya lebih homogen dan tidak lagi terlihat adanya bentuk 
kotoran ternak. Penggunaan mesin pencampur dan penghalus kotoran ternak tersebut dirasakan oleh peternak lebih menguntungkan. Walaupun alat tersebut merupakan bantuan yang dihibahkan, tetapi karena harganya terjangkau dan dapat memberikan hasil yang lebih ekonomis, maka kelompok peternak akan mampu membelinya secara mandiri. Kondisi ini diharapkan akan dapat meningkatkan animo masyarakat untuk membeli sekaligus menggunakan pupuk kompos asal ternak, sebagai ganti pupuk kimia. Hal ini akan meningkatkan antusias petani untuk beternak, karena selain mendapat hasil dari produksi ternak, juga akan mendapatkan tambahan penghasilan dari pengelolaan kotoran/limbah ternak. Penggunaan pupuk asal kotoran ternak sangat diperlukan untuk dapat mensubtitusi pupuk anorganik yang masih banyak digunakan. Nugraha dan Amini (2013) menyatakan bahwa untuk jangka panjang penggunaan pupuk an-organik akan mengikis unsur hara dan berbagai mineral penting dalam tanah, sehingga menyebabkan tanah menjadi kurang subur. Meningkatnya konsumen terhadap bahan makanan organik dapat meningkatkan keperluan pupuk asal kotoran ternak. Menurut Padmanabha dkk. (2014) pupuk kandang dapat meningkatkan kandungan N-total tanah. Pengabdian kepada masyarakat ini juga akan meningkatkan kesadaran pengelolaan limbah dan kotoran ternak yang akan berdampak terhadap peningkatan kesehatan lingkungan dan masyarakat. Berdasarkan penelitian Linggotu dkk. (2016) di wilayah kota Kotamobagu, propinsi Sulawesi Utara, tingkat pengetahuan, sikap dan keterampilan teknis para peternak dapat merupakan faktor penting yang mempengaruhi upaya kegiatan penanganan pencemaran lingkungan dari limbah kotoran ternak. Oleh karena itu, pendampingan kepada petani peternak masih sangat dibutuhkan dan sebaiknya dilaksanakan secara terus menerus sampai petani peternak dapat mandiri.

\section{KESIMPULAN}

Berdasar hasil kegiatan ini, disimpulkan bahwa pelatihan penggunaan mesin penghalus kotoran ternak dapat diterima oleh peternak dan akan direalisasikan setelah mengikuti pelatihan.

\section{UCAPAN TERIMA KASIH}

Kegiatan Pengabdian Kepada Masyarakat ini merupakan bagian dari PKM skim "Produk Teknologi Yang Didesiminasikan kepada Masyarakat" yang didanai oleh Kementerian Riset, Teknologi Dan Pendidikan Tinggi Tahun Anggaran 2020 dengan nomer kontrak: 1174/UN1/DPM/YANMAS/PM/2020.

\section{DAFTAR PUSTAKA}

Arifah SM. 2013. Aplikasi Macam Dan Dosis Pupuk Kandang Pada Tanaman Kentang. Jurnal Gamma. 8(2): 80-85.

Dirjen-PKH. 2019. Statistik Peternakan dan Kesehatan Hewan 2019. Jakarta: Direktorat Jenderal Peternakan dan Kesehatan Hewan. Kementerian Pertanian RI.

Ekantini A. 2020. Efektivitas Pembelajaran Daring pada Mata Pelajaran IPA di Masa Pandemi Covid- 
19: Studi Komparasi Pembelajaran Luring dan Daring pada Mata Pelajaran IPA SMP. Jurnal Pendidikan Madrasah. 5(2): 187-193.

Handayanta E, Rahayu ET, dan Sumiyati M. 2016. Analisis Finansial Usaha Peternakan Pembibitan Sapi Potong Rakyat Di Daerah Pertanian Lahan Kering. Sains Peternakan. 14(1): 13-20.

Hardianto. 2008. Petunjuk Teknis Pembuatan Bokasi. BPTP, Bandung.

Irfan, Rasdiansyah, dan Munadi M. 2017. Kualitas Bokasi Dari Kotoran Berbagai Jenis Hewan. Jurnal Teknologi dan Industri Pertanian Indonesia. 9(1): 23-27.

Juanda, Irfan, dan Nurdiana. 2011. Pengaruh Metode dan Lama Fermentasi terhadap Mutu MOL (Mikroorganisme Lokal). Floratek. 6(2): 140-143.

Linggotu LO, Paputungan U, dan Polii B. 2016. Pengelolaan Limbah Kotoran Ternak Dalam Upaya Pencegahan Pencemaran Lingkungan Di Kota Kotamobagu. Jurnal Zootek. 36(1): 226 - 237.

Matondang RH, dan Rusdiana S. 2014. Langkah-Langkah Strategis Dalam Mencapai Swasembada Daging Sapi/Kerbau 2014. J. Litbang Pert. 32(3):131-139.

Ngatirah N, dan Dewi CWA. 2020. Pelatihan Penggunaan Mesin Penggiling Jahe dan Pengolahan Limbah Ampas Jahe Menjadi Bubuk Jahe. Jurnal Pengabdian Masyarakat Berkemajuan. 4(1): 589-593.

Ningsih SR, Ahda Y, dan Handayani D. 2014. Pengaruh Penambahan Beberapa Cairan Rumen Terhadap Produksi Biogas dari Kotoran Sapi. Biospesies. 7(2): 34-42.

Nugraha SP, dan Amini FN. 2013. Pemanfaatan Kotoran Sapi Menjadi Pupuk Organik. Jurnal Inovasi dan Kewirausahaan. 2: 193-197.

Paramawati R, Triwahyudi S, Mardison M, Gultom RY. 2008. Rekayasa Mesin Penepung Tipe Double Jacket untuk Komoditas Biofarmaka. Jurnal Enjiniring Pertanian. 6(2): 93-98.

Padmanabha IG, Arthagama IDM, Dibia IN. 2016. Pengaruh Dosis Pupuk Organik dan Anorganik terhadap Hasil Padi (Oriza sativa L.) dan Sifat Kimia Tanah pada Inceptisol Kerambitan Tabanan. E-Jurnal Agroekoteknologi Tropika. 3: 41-50.

Pradja BP, dan Baist A. 2019. Analisis Kualitatif Penggunaan Microsoft Teams Dalam Pembelajaran Kolaboratif Daring. Prosiding SENATIK 4. Universitas PGRI, Semarang.

Putri NA, Suhartini S, dan Santosa EP. 2014. Pengaruh Paritas Terhadap Persentase Estrus Dan Kebuntingan Sapi Peranakan Ongole Yang Disinkronisasi Estrus Menggunakan Prostaglandin F2 $\alpha$ (PGF2 $\alpha$ ). J. Ilmiah Peternakan Terpadu. 2(2):31-36.

Sambodo P, Widayati I, Nurhayati D, Baaka A, Arizona A. 2020. Pemeriksaan Status Kesehatan Hewan Kurban Dalam Situasi Wabah Covid-19 Di Kabupaten Manokwari. IGKOJEI: Jurnal Pengabdian Masyarakat. 1(1): 7 -13.

Sambodo P, Prastowo J, Kurniasih K, Mubarokah WW, Indarjulianto S (2020). In vivo efficacy of Biophytum petersianum on Haemonchus contortus in goats. Adv. Anim. Vet. Sci. 8(3): 238-244.

Raden, I., Fadli, M., Efendi, A. 2014. Peran Pupuk Organik Kompos Berbasis Kotoran Hewan Terhadap Peningkatan Kesuburan Tanah Dan Produksi Bawang Merah (Allium ascalonicum L.). Magrobis Journal. 14(1): 36-43.

Rahmawati SD. 2009. Kendala Pelaksanaan Pembelajaran Jarak Jauh Melalui Internet Pada Mahasiswa Pjj S1 Pgsd Universitas Negeri Semarang. Skripsi. Kurikulum dan Teknologi Pendidikan, Fakultas Ilmu Pendididikan, Universitas Negeri Semarang.

Rigianti HA. 2020. Kendala Pembelajaran Daring Guru Sekolah Dasar di Banjarnegara. Elementary School. 7 (2): 297-302.

Taufiqurrahman M. 2020. Perkuliahan daring mata kuliah Ilmu Pendidikan Islam pada masa darurat Covid-19. Ta'dibuna: Jurnal Pendidikan Islam. 9(2): 213-224. 